\title{
In Vivo Bone-Targeting of Bis(phosphonate)- Conjugated Double Helical RNA Monitored by Positron Emission Tomography
}

Satish Jadhav, ${ }^{\text {a }}$ Meeri Käkelä, ${ }^{\text {b }}$ Matthieu Bourgery, ${ }^{\mathrm{c}}$ Kiira Rimpilä, ${ }^{\text {a }}$ Heidi Liljenbäck, ${ }^{\text {b,d }}$ Riikka Siitonen, ${ }^{\mathrm{b}}$ Jussi Mäkilä, ${ }^{\mathrm{b}, \mathrm{c}}$ Tiina Laitala-Leinonen, ${ }^{\mathrm{c}}$ Päivi Poijärvi-Virta, ${ }^{\mathrm{a}}$ Harri Lönnberg, ${ }^{\mathrm{a}}$ Anne Roivainen ${ }^{\mathrm{b}, \mathrm{d}}$ and Pasi Virta**

${ }^{a}$ Department of Chemistry, University of Turku, FI-20014 Turku, Finland

${ }^{b}$ Turku PET Centre, University of Turku and Turku University Hospital, FI-20521 Turku, Finland

${ }^{c}$ Department of Cell Biology and Anatomy, University of Turku, FI-20520 Turku, Finland

${ }^{d}$ Turku Center for Disease Modeling, University of Turku, FI-20520 Turku, Finland

\section{Contents:}

Figure S1. RP HPLC profile and MS (ESI-TOF) spectrum of 2

Table S1. Stability and protein binding based on ${ }^{68} \mathrm{Ga}$ radioactivity measurements

Figure S2. Representative radio HPLC chromatograms of the stability experiments 


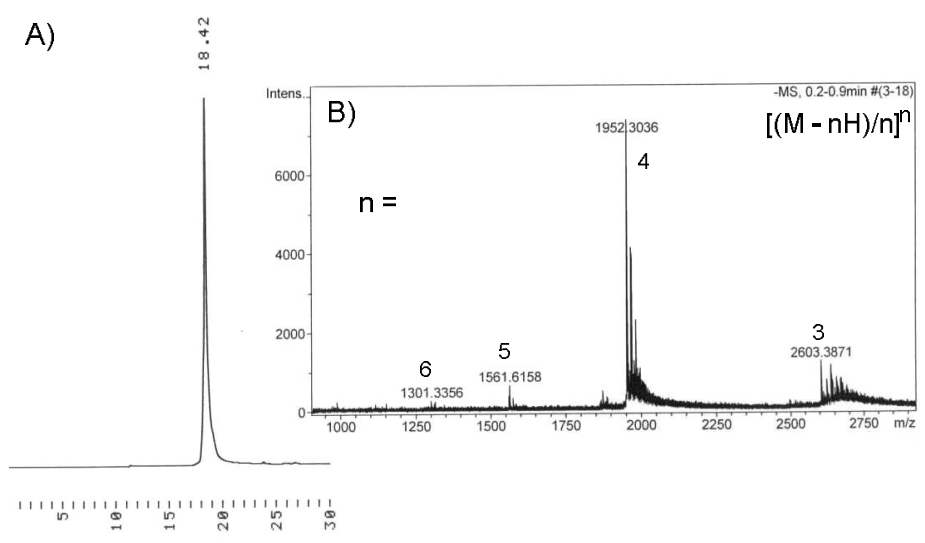

Figure S1. A) RP HPLC profile of 2, conditions: a semi-preparative (C-18, $250 \times 10 \mathrm{~mm}, 5 \mu \mathrm{m})$ column with a gradient elution from $0 \%$ to $35 \% \mathrm{MeCN}$ in aqueous $0.1 \mathrm{M} \mathrm{Et}_{3} \mathrm{NH}^{+} \mathrm{AcO}^{-}$over $25 \mathrm{~min}$, $3.0 \mathrm{mM}$ flow rate and detection wavelength at $260 \mathrm{~nm}$; B) MS (ESI-TOF) spectrum of purified 2. 
Table S1. Stability and protein binding based on ${ }^{68} \mathrm{Ga}$ radioactivity measurement

\begin{tabular}{cccccc}
\hline & \multicolumn{3}{c}{ Stability $(\%)$} & Protein binding (\%) \\
\cline { 2 - 6 } oligoribonucleotides & $\begin{array}{c}\text { In vitro } \\
\text { r.t. 3h }\end{array}$ & $\begin{array}{c}\text { In vitro } \\
+37^{\circ} \mathrm{C} \text { rat's plasma 1h }\end{array}$ & $\begin{array}{c}\text { In vivo } \\
\text { rat's plasma 1h }\end{array}$ & $\begin{array}{c}\text { In vivo } \\
\text { rat's urine } 1 \mathrm{~h}\end{array}$ & $\begin{array}{c}\text { In vitro } \\
+37^{\circ} \mathrm{C} \text { rat's plasma }\end{array}$ \\
\hline $\mathbf{1}\left[{ }^{68} \mathrm{Ga}\right]$ alone & 97 & $98 \pm 0.4$ & 11 & 81 & $31 \pm 2.1$ \\
$\mathbf{1}\left[{ }^{68} \mathrm{Ga}\right]+1$ equiv of $\mathbf{2}$ & 91 & $89 \pm 3.2$ & 28 & 88 & $72 \pm 2.3$ \\
$\mathbf{1}\left[{ }^{68} \mathrm{Ga}\right]+2$ equiv of $\mathbf{2}$ & 93 & $87 \pm 3.4$ & 18 & 84 & $80 \pm 4.4$ \\
$\mathbf{1}\left[{ }^{68} \mathrm{Ga}\right]+$ 4 equiv of $\mathbf{2}$ & 90 & $90 \pm 0.8$ & 38 & 91 & $76 \pm 0.5$ \\
\hline
\end{tabular}
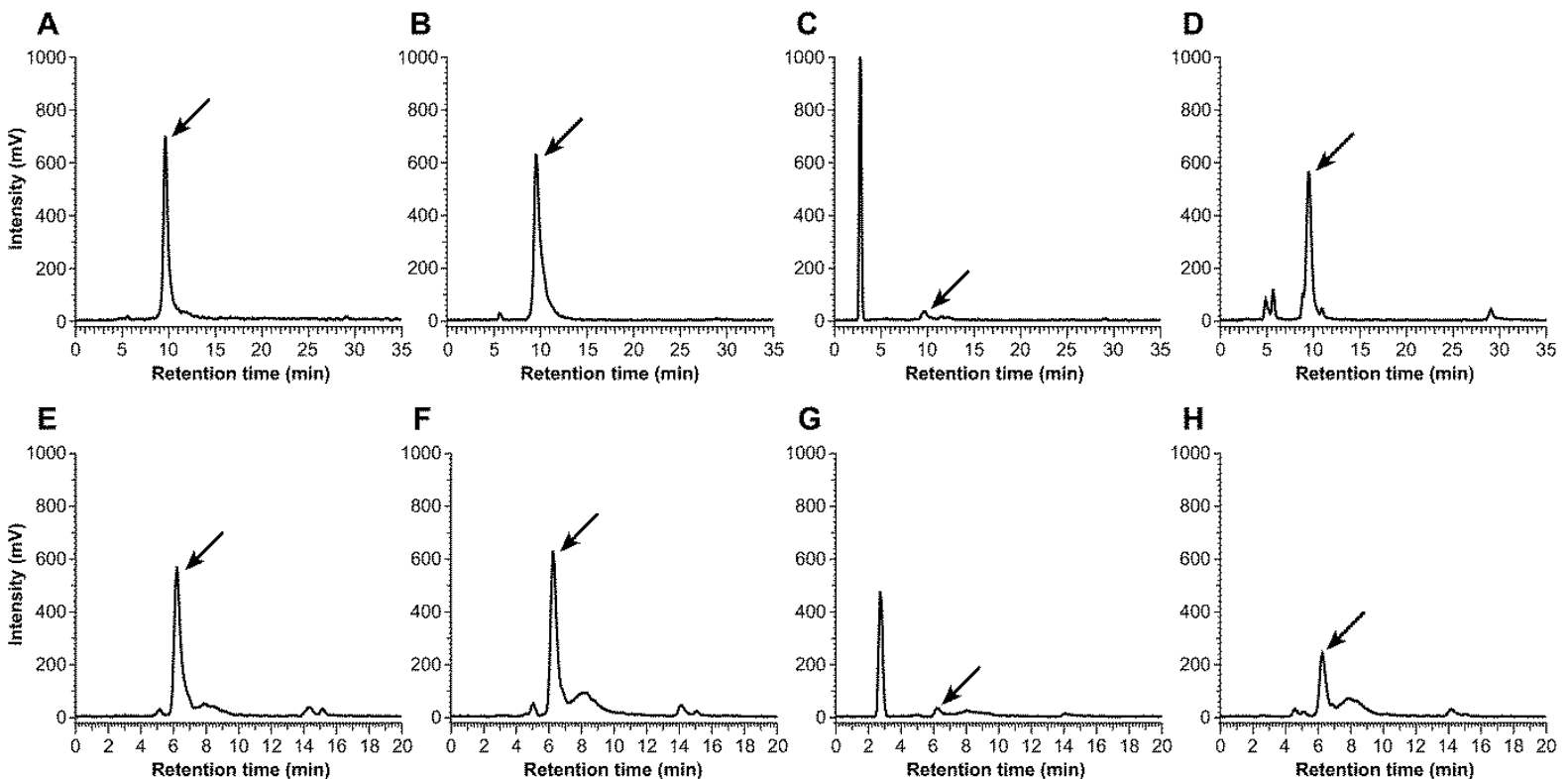

Figure S2. Representative radio HPLC chromatograms of the stability experiments. A) $\left.\mathbf{1}^{68} \mathrm{Ga}\right]$ alone incubated for 3 hours at room temperature; B) $\mathbf{I}^{68} \mathrm{Ga}$ ] alone, 1 hour, rat's plasma in vitro, $+37^{\circ} \mathrm{C} ; \mathbf{C}$ $\mathbf{1}\left[{ }^{68} \mathrm{Ga}\right]$ alone, 1 hour, rat's plasma in vivo; D) $\mathbf{1}\left[{ }^{68} \mathrm{Ga}\right]$ alone, 1 hour, rat's urine in vivo; E) $\mathbf{1}\left[{ }^{68} \mathrm{Ga}\right] / \mathbf{2}$ duplex $(1: 1, n / n), 3$ hours, at room temperature; F) $\left.\mathbf{I}^{68} \mathrm{Ga}\right] / \mathbf{2}$-duplex $(1: 1, n / n), 1$ hour, rat's plasma in vitro, $+37^{\circ} \mathrm{C}$; G) $\mathbf{1}\left[{ }^{68} \mathrm{Ga}\right] / \mathbf{2}$-duplex $(1: 1, n / n)$, plasma in vivo; H) $\left.\mathbf{1}^{68} \mathrm{Ga}\right] / \mathbf{2}$-duplex $(1: 1, n / n), 1$ hour, rat's urine in vivo. For the radio-HPLC analysis: a preparative RP HPLC column (C-18, $300 \times 7.8 \mathrm{~mm}$, $125 \AA$ ) with a gradient elution from 0 to $50 \%$ acetonitrile in $50 \mathrm{mM} \mathrm{NH}{ }_{4} \mathrm{OAc}$ over $25 \mathrm{~min}$ (A-D) and 11 min (E-H), continued then $50 \%$ acetonitrile in $50 \mathrm{mM} \mathrm{NH}_{4} \mathrm{OAc}$, followed by washing with aqueous 50 $\mathrm{mM} \mathrm{H}_{3} \mathrm{PO}_{4}$ was used. The retention times of ${ }^{1}\left[{ }^{68} \mathrm{Ga}\right]$ in chromatograms A-D are 9.65, 9.53, 9.64 and $9.46 \mathrm{~min}$, respectively. The retention times of $\left.1{ }^{68} \mathrm{Ga}\right]+\mathbf{2}$ in chromatograms $\mathrm{E}-\mathrm{H}$ are $6.22,6.23,6.21$ and $6.27 \mathrm{~min}$, respectively. 